\title{
Substantial Carbohydrate Hydrolase Activities in the Water Column of the Guaymas Basin (Gulf of California)
}

\author{
Kai Ziervogel ${ }^{1 *}$ and Carol Arnosti ${ }^{2}$ \\ ${ }^{1}$ Institute for the Study of Earth, Oceans and Space, University of New Hampshire, Durham, NH, United States, \\ ${ }^{2}$ Department of Marine Sciences, The University of North Carolina at Chapel Hill, Chapel Hill, NC, United States
}

\section{OPEN ACCESS}

Edited by:

Gordon T. Taylor,

Stony Brook University, United States

Reviewed by:

Maria Montserrat Sala,

Institute of Marine Sciences (CSIC),

Spain

Brian Gaas,

Government of Yukon, Canada

*Correspondence:

Kai Ziervogel

kai.ziervoge/@unh.edu

Specialty section:

This article was submitted to Marine Biogeochemistry,

a section of the journal

Frontiers in Marine Science

Received: 08 September 2019 Accepted: 17 December 2019

Published: 15 January 2020

Citation:

Ziervogel K and Arnosti C (2020) Substantial Carbohydrate Hydrolase Activities in the Water Column of the

Guaymas Basin (Gulf of California).

Front. Mar. Sci. 6:815.

doi: 10.3389/fmars.2019.00815
The Guaymas Basin spreading center situated in the Gulf of California is characterized by a thick layer of organic-rich sediments that are thermally altered by hydrothermal fluids, thereby providing a bottom water source of dissolved organic carbon (DOC) to the water column. The potential for heterotrophic microbial communities in the water column to metabolize this organic matter source has not yet been investigated, however. In order to assess heterotrophic potential in the water column of the Guaymas Basin, we measured the activities of carbohydrate-hydrolyzing extracellular enzymes at the chlorophyll maximum, the oxygen minimum, the deep-water turbidity plume, and bottom waters. These measurements were carried out using water obtained from repeat CTD casts over the course of a week, and from bottom water collected by HOV Alvin at hydrothermally active areas with extensive chemosynthetic microbial mats. Repeat measurements at subsurface depths were very comparable across sampling dates and CTD casts. Exoacting (terminal-unit-cleaving) monosaccharide hydrolase activities were typically higher in deeper waters than in surface waters, despite colder temperatures. In bottom water, the spectrum of endo-acting (mid-chain-cleaving) polysaccharide hydrolase activities was broader than at shallower depths. The high enzyme activities in Guaymas Basin bottom waters indicate an unusually active heterotrophic community that is responding to influx of DOC and nutrients into bottom waters from the hydrothermally affected sediments, or to the availability of chemosynthetically produced biomass.

Keywords: heterotrophic activity, extracellular enzymes, polysaccharides, dissolved organic carbon, hydrothermal vent, water column, Gulf of California, Guaymas Basin

\section{INTRODUCTION}

The Guaymas Basin is part of a spreading center that underlies highly productive surface waters in the Gulf of California (Kahru et al., 2004). The flux of organic matter from the surface has accumulated to a sediment layer several hundred meters in thickness (Einsele et al., 1980; Schrader et al., 1980) that is substantially modified by the passage of hydrothermal fluids (Simoneit et al., 1979; Von Damm et al., 1985). This organic matter fuels a diverse community of benthic microbes carrying out autotrophic and heterotrophic processes based on the flux of reduced elements into the water column as well as the availability of hydrothermally-produced petroleum products (Teske et al., 2002, 2014; Dombrowski et al., 2018).

The water column of the Guaymas Basin is also greatly affected by hydrothermal activity, with plumes of vent fluids influencing the chemistry of the water column below the basin 
sill depth of $1560 \mathrm{~m}$ (Campbell and Gieskes, 1984). Previous research has demonstrated the presence of autotrophic microbes and autotrophic production fueled by reduced metals, sulfur and hydrogen metabolism (e.g., Anantharaman et al., 2013). Active seeping of fluids from the organic-rich sediments carries high concentrations of dissolved organic carbon (DOC) into the water column (Lin et al., 2017). This DOC could potentially stimulate activities of heterotrophic microbes, providing a source of organic substrates at depth that could supplement the sinking flux of particulate organic carbon from the surface ocean. This possibility has not yet been investigated, however.

Here we report results of a survey of heterotrophic microbial activities in the water column of the Guaymas Basin. We focused on measurement of the activities of extracellular enzymes that catalyze the initial step in microbial degradation of high molecular weight (HMW) substrates. These enzymes are selective for specific structural features and hydrolyze HMW substrates to sizes sufficiently small for cellular uptake (Arnosti, 2011). The focus here is on carbohydrate-hydrolyzing enzymes, which are responsible for hydrolysis of a major class of marine organic matter. Two general modes of hydrolysis characterize extracellular enzymes: exo-acting extracellular enzymes cleave subunits from ends of a chain, while endo-acting enzymes cleave HMW substrates mid-chain. We used an array of different substrate proxies and HMW polysaccharides to measure both categories of enzyme activities. Measurements of carbohydratehydrolyzing enzyme activities in surface waters are quite common; there are far fewer measurements of exo-acting (Baltar et al., 2009, 2010) and endo-acting (Hoarfrost and Arnosti, 2017; Balmonte et al., 2018) carbohydrate hydrolase activities in the deep ocean. Sampling in the Guaymas Basin provides the opportunity to assess microbial heterotrophic activities in an environment that is potentially fueled with substrates from the bottom as well as from the surface ocean. Repeat CTD casts and water samples collected from HOV Alvin over the course of the cruise provided the opportunity to assess the range and variability of heterotrophic enzyme activities in this hydrothermally affected location.

\section{MATERIALS AND METHODS}

\section{Sampling and Site Description}

Water column samples were collected in the southern trough of the Guaymas Basin aboard RV Atlantis (AT15-56). Water column samples were taken from the depth of the deep chlorophyll maximum (DCM), the lower part of the oxygen minimum zone (OMZ), deep water turbidity plumes (Plume; $\sim 200 \mathrm{~m}$ above seafloor), and bottom waters (Bottom; $\sim 50 \mathrm{~m}$ above seafloor) with Niskin bottles mounted on a CTD rosette (CTD profiles are published on figshare). Samples from these four depths were taken during five CTD deployments (hereafter referred to as CTD1-CTD5) between November 22 and December 01, 2009, within an area of approximately $5000 \mathrm{~m}^{2}$. Near bottom water samples ( $\sim 2 \mathrm{~m}$ above seafloor) were retrieved by a Niskin bottle mounted on the Human Occupied Vehicle (HOV) Alvin during four dives in the same area as the
TABLE 1 | Sampling sites and water column parameters.

\begin{tabular}{|c|c|c|c|c|c|}
\hline $\begin{array}{l}\text { Sample } \\
\text { ID }\end{array}$ & Lat/Long & $\begin{array}{l}\text { Sampling depth, } \\
\text { description }\end{array}$ & $\begin{array}{l}\text { Temp } \\
\left({ }^{\circ} \mathrm{C}\right)\end{array}$ & $\begin{array}{l}\text { DOC } \\
(\mu \mathrm{M})\end{array}$ & $\begin{array}{l}\text { Bacterial } \\
\text { cells }\left(L^{-1}\right)\end{array}$ \\
\hline \multirow[t]{3}{*}{ CTD 1} & $\begin{array}{l}27^{\circ} 00.45 \mathrm{~N} \\
111^{\circ} 24.51 \mathrm{~W}\end{array}$ & 50 m, DCM & 24.5 & $234 \pm 2.2$ & $1.2 E+08$ \\
\hline & & 900 m, OMZ & 4.9 & $131 \pm 2.3$ & $5.1 E+07$ \\
\hline & & 1950 m, Bottom & 2.9 & $1292 \pm 13.4$ & $5.8 \mathrm{E}+07$ \\
\hline \multirow[t]{2}{*}{ CTD 2} & $\begin{array}{l}27^{\circ} 00.47 \mathrm{~N} \\
111^{\circ} 24.41 \mathrm{~W}\end{array}$ & 50 m, DCM & 23.7 & $241 \pm 5.6$ & n.a. \\
\hline & & 1950 m, Bottom & 2.9 & $160 \pm 3.5$ & n.a. \\
\hline \multirow[t]{4}{*}{ CTD 3} & $\begin{array}{l}27^{\circ} 00.47 \mathrm{~N} \\
111^{\circ} 24.39 \mathrm{~W}\end{array}$ & 50 m, DCM & 24.1 & $192 \pm 1.2$ & $1.3 E+08$ \\
\hline & & 920 m, OMZ & 4.9 & $329 \pm 5.7$ & $7.9 \mathrm{E}+07$ \\
\hline & & 1800 m, Plume & 2.9 & $148 \pm 1.5$ & $6.4 \mathrm{E}+07$ \\
\hline & & 1950 m, Bottom & 2.9 & $785 \pm 5.4$ & $1.3 E+08$ \\
\hline \multirow[t]{4}{*}{ CTD 4} & $\begin{array}{l}27^{\circ} 00.46 \mathrm{~N} \\
111^{\circ} 24.44 \mathrm{~W}\end{array}$ & 50 m, DCM & 23.9 & $464 \pm 3.2$ & $1.5 E+08$ \\
\hline & & 890 m, OMZ & 4.9 & $847 \pm 2.6$ & $1.1 E+08$ \\
\hline & & 1800 m, Plume & 2.9 & $636 \pm 7.4$ & $6.5 E+07$ \\
\hline & & 1950 m, Bottom & 2.9 & $121 \pm 2.0$ & $8.5 E+07$ \\
\hline \multirow[t]{4}{*}{ CTD 5} & $\begin{array}{l}27^{\circ} 00.43 \mathrm{~N} \\
111^{\circ} 24.45 \mathrm{~W}\end{array}$ & $50 \mathrm{~m}, \mathrm{DCM}$ & 22.5 & $157 \pm 2.6$ & n.a. \\
\hline & & 845 m, OMZ & 5.3 & $1647 \pm 2.8$ & n.a. \\
\hline & & 1815 m, Plume & 2.9 & $237 \pm 2.9$ & n.a. \\
\hline & & 1950 m, Bottom & 2.9 & $141 \pm 1.7$ & n.a. \\
\hline $\begin{array}{l}\text { Dive } \\
4563\end{array}$ & $\begin{array}{l}27^{\circ} 00.47 \mathrm{~N} \\
111^{\circ} 24.43 \mathrm{~W}\end{array}$ & $\begin{array}{l}2009 \text { m, Above } \\
\text { patch of white, } \\
\text { yellow and orange } \\
\text { mat }\end{array}$ & 2.9 & $303 \pm 2.5^{*}$ & $4.1 E+07$ \\
\hline $\begin{array}{l}\text { Dive } \\
4565\end{array}$ & $\begin{array}{l}27^{\circ} 00.70 \mathrm{~N} \\
111^{\circ} 24.27 \mathrm{~W}\end{array}$ & $\begin{array}{l}2010 \text { m, } \\
\text { Cathedral Hill: } \\
\text { yellow and white } \\
\text { sediment near } \\
\text { massive structure } \\
\text { of hydrothermal } \\
\text { deposits }\end{array}$ & 2.9 & $2112 \pm 13.6^{*}$ & $5.1 E+07$ \\
\hline $\begin{array}{l}\text { Dive } \\
4567\end{array}$ & $\begin{array}{l}27^{\circ} 00.54 \mathrm{~N} \\
111^{\circ} 24.49 \mathrm{~W}\end{array}$ & $\begin{array}{l}2011 \mathrm{~m}, \\
\text { Reference site, } \\
\text { non-hydrothermal } \\
\text { brown sediment }\end{array}$ & 2.9 & $698 \pm 6.9^{*}$ & $7.8 \mathrm{E}+07$ \\
\hline $\begin{array}{l}\text { Dive } \\
4570\end{array}$ & $\begin{array}{l}27^{\circ} 00.47 \mathrm{~N} \\
111^{\circ} 24.43 \mathrm{~W}\end{array}$ & $\begin{array}{l}2010 \text { m, Large } \\
\text { orange and white } \\
\text { Beggiatoa mat }\end{array}$ & 2.9 & $111 \pm 2.4^{*}$ & $8.7 \mathrm{E}+07$ \\
\hline
\end{tabular}

Temp, water temperature; DOC, dissolved organic carbon; n.a., means not available; *means data were previously published in Lin et al. (2017).

CTD deployments. The sediments ranged from hydrothermally active to bare sediments (see Table 1 for a detailed description of sampling sites). Previously reported DOC concentrations in waters above the sediment were highly variable, ranging between $300 \mu \mathrm{M}$ (Dive 4563) to over $2000 \mu \mathrm{M}$ (Dive 4565) (Lin et al., 2017).

\section{Measurements of Hydrolytic Enzyme Activities}

Enzyme activities were measured using two experimental approaches that provide different information about the activities of specific types of enzymes. The first approach 
used MUF- $\alpha$-D-glucopyranoside (a-glu), MUF- $\beta-D-$ glucopyranoside (b-glu), MUF- $\beta$-D-fucoside (b-fu), and MUF- $\beta$-D-xylopyranoside (b-xyl) (all Sigma-Aldrich) as small substrate proxies to measure activities of exo-acting enzymes, which cleave terminal units from carbohydrates (Hoppe, 1983). These activities can be measured with short-term (several hour) incubations, reflecting enzymatic responses of the microbial community present in the sample at the time the substrate is added. Enzyme assays with the four substrate proxies were conducted in all of the samples in Table 1 except for b-glu in CTD 4 (OMZ) and CTD 5 (all depths) due to a shortage of substrate. Incubations were conducted in replicate $4 \mathrm{~mL}$ acrylic cuvettes $(n=3)$ containing single substrates at enzyme-saturating levels (15 $\mu \mathrm{M}$ final concentration; determined at the beginning of the expedition) and $1.5 \mathrm{~mL}$ of seawater. The cuvettes were incubated in the dark for up to $12 \mathrm{~h}$. Incubation temperatures were close to in situ temperatures (DCM: $20^{\circ} \mathrm{C}$; OMZ: $5^{\circ} \mathrm{C}$; Plume: $5^{\circ} \mathrm{C}$; Bottom and near bottom: $3^{\circ} \mathrm{C}$ ). Fluorescence was measured at the beginning and the end point using a Turner Biosystems TBS-380 fluorometer, with excitation/emission channels set to "UV" (365 nm excitation, 440-470 nm emission). Control cuvettes were prepared with artificial seawater (Sea salts, $38 \mathrm{~g} \mathrm{~L}^{-1}$; Sigma) and MUF-substrates and incubated under the same conditions as the live cuvettes to control for abiotic substrate degradation, which was always minor. Fluorescence changes over time were calibrated using MUF standard and used to calculate potential hydrolysis rates.

The second experimental approach measured the activities of specific endo-acting enzymes that cleave target polysaccharides mid-chain. These experiments require comparatively long incubation times and therefore integrate microbial enzymatic induction and growth responses (including possible changes in community composition) to substrate addition. Longer incubation times are necessary because the time that is required for a polysaccharide pool to be hydrolyzed to lower molecular weights is not known a priori (Arnosti, 2003). Endo-acting enzyme activities were measured at three depths (DCM, OMZ, Bottom) in CTD 1, and in Alvin-collected water (Dive 4567, 4565) using fluorescently-labeled (FLA) pullulan, laminarin, xylan, and fucoidan (polysaccharides from Fluka or Sigma). The four polysaccharides differ in monomer composition and linkage position; they are components of marine algae (Painter, 1983) and are therefore present in considerable quantities in the ocean (Alderkamp et al., 2007). Moreover, activities of enzymes that specifically hydrolyze these substrates have been measured in a variety of marine environments (Arnosti et al., 2011), and genes corresponding to these enzymes have been identified in the genomes of marine bacterial isolates (Weiner et al., 2008; Wegner et al., 2013; Kabisch et al., 2014).

The substrates were labeled with fluoresceinamine and used to measure extracellular enzyme activities as described in Arnosti (1996, 2003). In brief, single substrates were added to $15 \mathrm{ml}$ of samples water at a final concentration of $3.5 \mu \mathrm{M}$ monomer equivalent. Two replicate vials per substrate and sample were prepared and incubated in the dark for 21 days at close to in situ temperature (see above). Throughout the incubation, $1 \mathrm{~mL}$ subsamples were taken after $0,1.5,4,7,11$, and
21 days (CTD cast) and after $0,1,3,7$, and 14 days (Alvin water). Subsamples were immediately filtered through $0.2-\mu \mathrm{m}$ surfactant free cellulose acetate (SFCA) syringe filters and the filtrate was stored at $-20^{\circ} \mathrm{C}$ until analysis on a gel-permeation chromatography system with fluorescence detection, as described in detail in Arnosti (2003). The maximum hydrolysis rate among all time points in a sample was used as a measure of the maximum potential rate at which the microbial community could access a specific polysaccharide. Control incubations with artificial seawater did not reveal abiotic substrate degradation.

All rates reported here represent potential hydrolysis rates, as added substrate competes with naturally occurring substrates for active enzyme sites. Given the level of substrate addition, however, hydrolysis rates are likely zero order with respect to substrate and represent maximum potential rates.

\section{Bacterial Cell Counts}

Bacterial cells were fixed with formalin (2\% final conc.) and stained with 4', 6-diamidino-2-phenylindole (DAPI; Porter and Feig, 1980) on a $0.2-\mu \mathrm{m}$ polycarbonate filter. Either 40 frames of view or 200 cells were counted per slide using epifluorescence microscopy (Olympus, magnification $\times 1000$ ).

\section{Dissolved Organic Carbon (DOC)}

Water was filtered through $0.2-\mu \mathrm{m}$ SFCA syringe filters and stored at $-20^{\circ} \mathrm{C}$ in precombusted scintillation vials until analysis. Thawed samples were acidified with phosphoric acid (50\% v/v) and analyzed by high temperature catalytic oxidation using a Shimadzu TOC-5000. Replicate measurements of a single sample $(n=6)$ were used to calculate average DOC centration \pm standard deviations. Note that DOC concentrations in waters collected during Alvin dives 4563, 4565, 4567, 4570 were previously reported in Lin et al. (2017).

\section{Statistical Analysis}

Differences in hydrolysis rates (averages of $n=3$ ) were tested with one-way ANOVAs and Student's $t$-test at the $5 \%$ significance level. Results from ANOVAs were compared with Tukey's post hoc test. Statistical analysis was conducting using JMP Pro 14 software.

\section{RESULTS}

Water column CTD profiles were very similar to the composite profile of Guaymas Basin from Campbell and Gieskes (1984). Water temperature was $24^{\circ} \mathrm{C}$ at the $\mathrm{DCM}, 4.9^{\circ} \mathrm{C}$ at the $\mathrm{OMZ}$, and $2.9^{\circ} \mathrm{C}$ at the bottom (Table 1). Beam transmissometry data suggest presence of significant quantities of particles in lower portion of water column, including the 1800 and $1950 \mathrm{~m}$ sampling depths; these are likely due to abundant Mn oxides in the water column (Lesniewski et al., 2012).

DOC concentrations were generally higher at depths below the DCM than at the DCM, except for CTD 2 (Table 1). Highest DOC levels at $2112 \pm 13.6 \mu \mathrm{M}$ were found in Alvin water near a massive structure of hydrothermal deposits (Dive 4565). Bacterial 


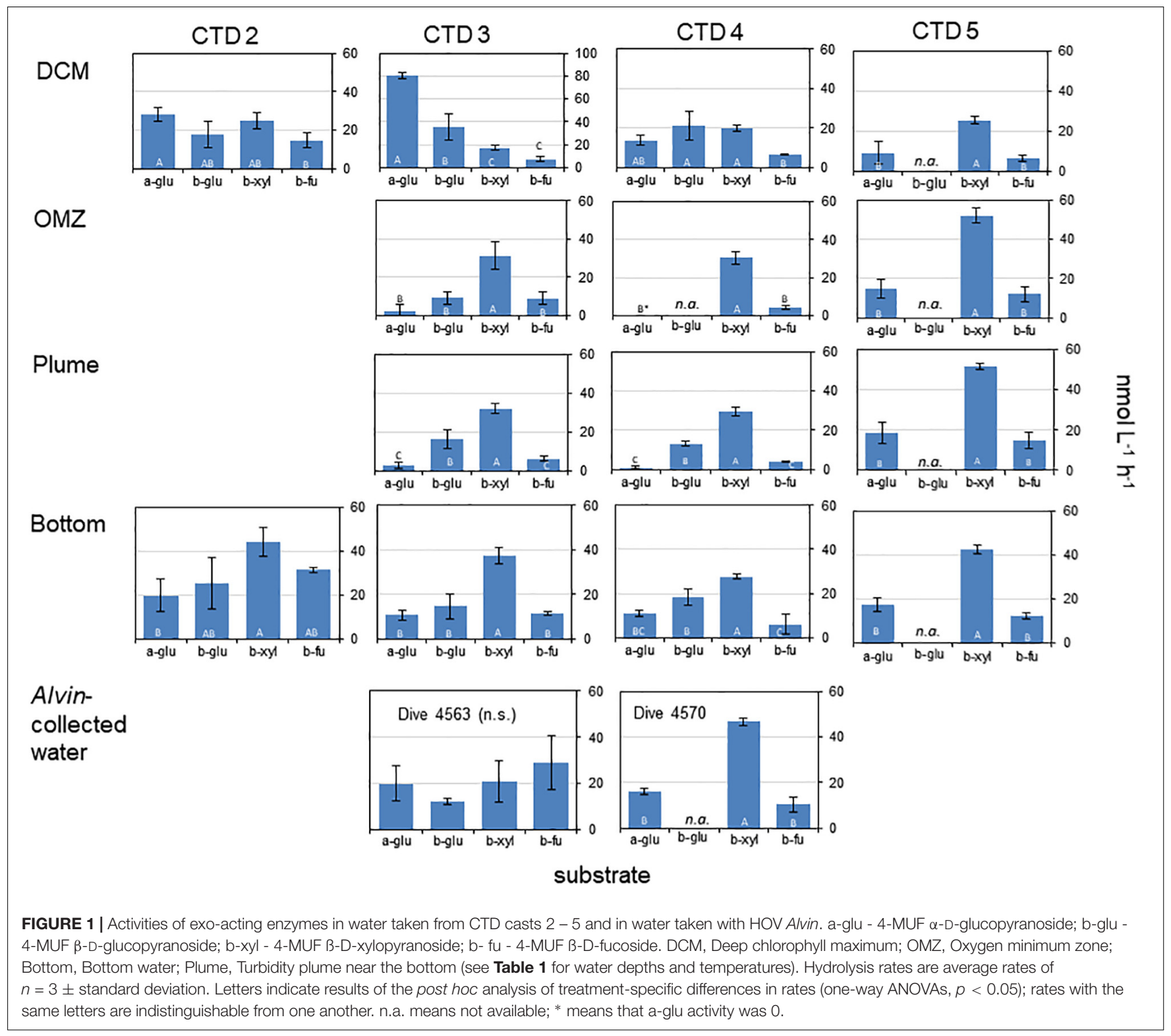

cell numbers at $50 \mathrm{~m}$ were somewhat higher (CTD 1 and CTD 4) or at the same level (CTD 3) than those at the bottom.

Activities of exo-acting enzymes (a-glu, b-glu, b-xyl, b-fu) were measurable at all depths for all CTD casts, with the exception of a-glu at OMZ for CTD4 where no activity was measurable (Figure 1).

Two particularly notable features stand out: despite a strong water column temperature gradient between the DCM and the depths below $50 \mathrm{~m}$, rates of exo-acting enzyme activities did not decrease systematically with depth. This pattern was most pronounced for b-xyl activities that were always more rapid at the depths below $50 \mathrm{~m}$ than at $50 \mathrm{~m}$. For CTD 2, activities of b-fu were also higher at the bottom compared to the DCM (Table 2). In addition, the patterns of enzyme activities - a high level of b-xyl activity, which was approximately twice as high as the other activities - was similar for all subsurface depths of all CTD casts (Figure 1). At the DCM, patterns of enzyme activities varied more among casts. At this depth, a-glu activities varied by a factor of ca. 8 among casts, and b-glu and $\mathrm{b}$-fu activities varied by a factor of approximately 2 among casts; b-xyl activities were similar among casts, with average activities ranging from $\sim 17$ to $25 \mathrm{nmol} \mathrm{L} \mathrm{L}^{-1} \mathrm{~h}^{-1}$. The range of exo-acting activities (approximately 12-46 nmol $\mathrm{L}^{-1} \mathrm{~h}^{-1}$ ) in Alvin-collected water was similar to the range of activities measured in water collected at depths of 1800 and $1950 \mathrm{~m}$; b-xyl activities were notably higher than the other activities in Dive 5470 water, however.

Only 2 of the 4 polysaccharide hydrolase activities (laminarinase and pullulanase) were measurable at the DCM and OMZ; hydrolysis of laminarin and pullulan were a factor of 2-4 times highest at the DCM compared with the OMZ and Bottom. Xylanase activity was also measurable at the bottom 
TABLE 2 | Results from post hoc comparison of depth-specific differences in exo-acting enzyme activities following a one-way ANOVA or a T-Test (CTD 2 only) with $p<0.05$.

\begin{tabular}{lcccc}
\hline Substrate, sample & CTD 2 & CTD 3 & CTD 4 & CTD 5 \\
\hline a-glu, DCM & n.s. & A & A & n.s. \\
a-glu, OMZ & & C & B & \\
a-glu, Plume & & C & B & \\
a-glu, Bottom & & B & A & n.s. \\
b-glu, DCM & n.s. & A & & \\
b-glu, OMZ & & B & & C \\
b-glu, Plume & & B & & A \\
b-glu, Bottom & & B & & A \\
b-xyl, DCM & B & B & B & B \\
b-xyl, OMZ & n.a. & A & A & A.s. \\
b-xyl, Plume & n.a. & A & A & A \\
b-xyl, Bottom & A & A & A & \\
b-fu, DCM & B & n.s. & n.s. & \\
b-fu, OMZ & n.a. & & & \\
b-fu, Plume & n.a. & & & \\
b-fu, Bottom & A & & & \\
b & & &
\end{tabular}

Letter A indicates highest activity, letter B indicates intermediate activity, and letter $C$ indicates lowest activity. n.s. means not significant; n.a. means not available.

at a rate that was faster than for laminarinase or pullulanase activities. Fucoidan hydrolysis was not detected in any depths of CTD 1. All 4 polysaccharides tested here, including Fucoidan, were hydrolyzed in Alvin-collected water, however. Considerable fucosidase activity (2.5-3.3 nmol monomer $\mathrm{L}^{-1} \mathrm{~h}^{-1}$ ) was measurable in water collected above a microbial mat (Dive 4565) and in water collected over bare sediment (Dive 4567) (Figure 2). Xylan hydrolysis was also measurable (in one of two replicates for Dive 4567; at trace levels in water from Dive 4565), and hydrolysis of laminarin and pullulan was comparable to rates measured in bottom water.

\section{DISCUSSION}

The Guaymas Basin has considerable hydrothermal input that is retained to some extent at depths below its sill at $1560 \mathrm{~m}$ (Campbell and Gieskes, 1984), resulting in deep water that is hydrothermally affected and has a longer residence time than comparable depths in the open ocean. Focused investigations of microbial communities in the water column of the Guaymas Basin have centered primarily on comparisons between the sedimentary and water column communities (e.g., Dick and Tebo, 2010; Dick et al., 2013), and on autotrophic organisms that may thrive on the hydrothermal input of sulfur and reduced metals (Lesniewski et al., 2012; Anantharaman et al., 2013; Dick, 2019). The thick layer of organic matter blanketing the system (Simoneit et al., 1979; Schrader et al., 1980), however, is the source of a substantial flux of DOC from the sediments to the deep waters of the basin (Table 1; Lin et al., 2017), in addition to input of sinking POC from the productive surface waters.

The high activities of exo-acting enzymes, and the observation that these rates do not generally decrease with depth in the

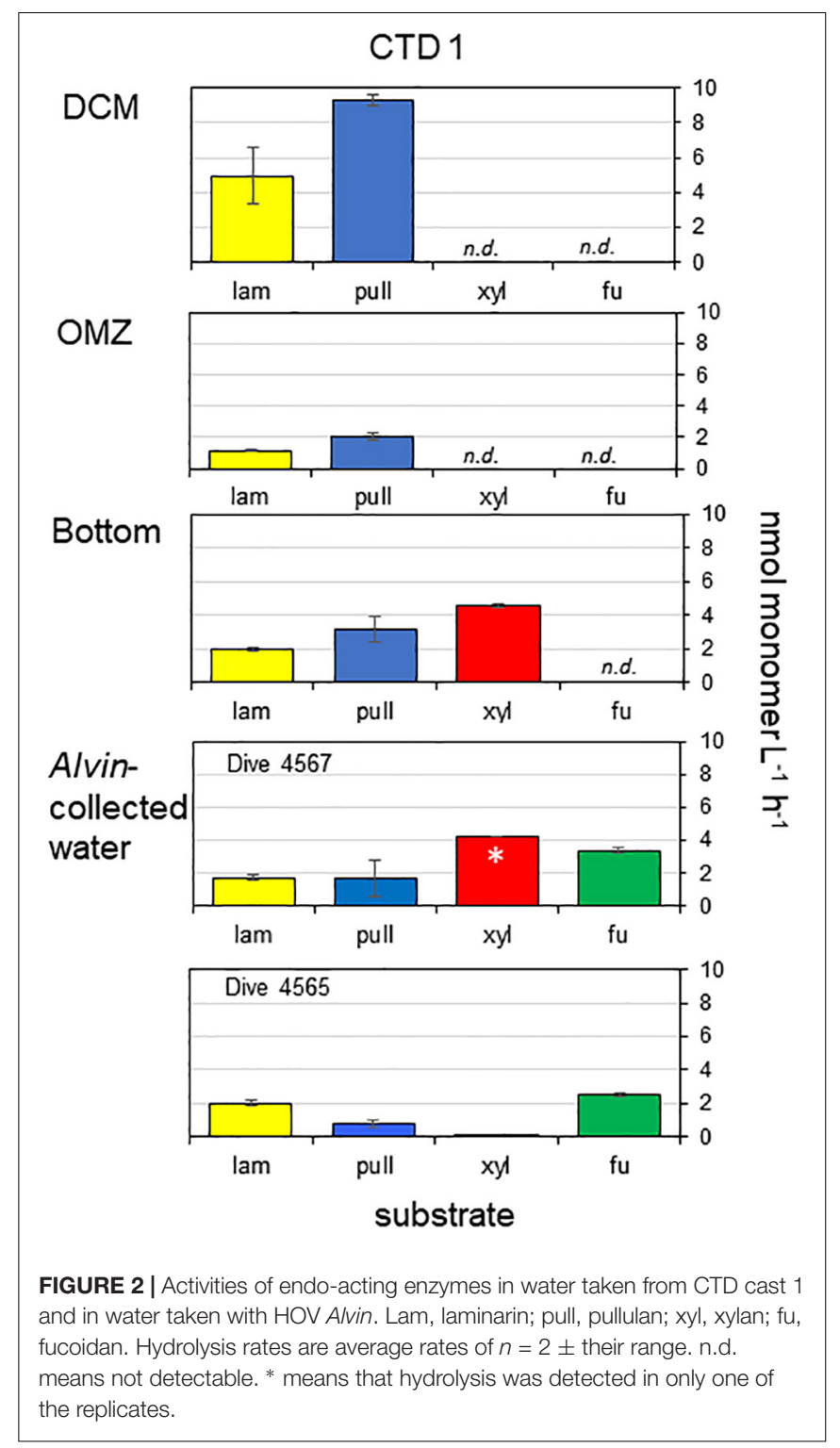

Guaymas Basin (Figure 1), indicate the presence of highly active heterotrophic microbial communities throughout the water column. Rates of b-glu, for example, ranged from 9 to $25 \mathrm{nmol} \mathrm{L}{ }^{-1} \mathrm{~h}^{-1}$ over the depth range of 845-1950 m (Figure 1); at comparable depths in the central Atlantic Ocean, for example, rates of $0.05-0.25 \mathrm{nmol} \mathrm{L}^{-1} \mathrm{~h}^{-1}$ have been reported (Baltar et al., 2010), and in the subtropical Atlantic, rates at comparable depths ranged from ca. 0.02-0.04 nmol $\mathrm{L}^{-1} \mathrm{~h}^{-1}$ (Baltar et al., 2009). Activities of a-glu were similar or lower than b-glu activities in the Atlantic (Baltar et al., 2009, 2010); in the Guaymas Basin, they were also in general similar to or lower than b-glu activities, but were substantially higher than at similar depths in the Atlantic Ocean, ranging from ca. $1-19 \mathrm{nmol} \mathrm{L}^{-1} \mathrm{~h}^{-1}$ (Figure 1). Activities of a-glu at the DCM were similar to or higher than rates reported for the southwest Atlantic (Hoarfrost and Arnosti, 2017) and higher than rates reported in the surface waters of the Adriatic Sea (Karner et al., 1992). 
Although b-xyl activities are frequently measured in terrestrial systems, there are few data on b-xyl activities from marine waters (Alonso-Sáez et al., 2008), and somewhat more data from rivers (e.g., Kirchman et al., 2004). Activities measured in the Guaymas Basin (17 to $52 \mathrm{nmol} \mathrm{L}^{-1} \mathrm{~h}^{-1}$ ) considerably exceed activities measured in the Hudson River (range of 3-10 pmol L ${ }^{-1} \mathrm{~h}^{-1}$; Kirchman et al., 2004) and were on average somewhat higher than a site in the northwest Mediterranean Sea, where rates ranged from 1 to $46 \mathrm{nmol} \mathrm{L}^{-1} \mathrm{~h}^{-1}$ (AlonsoSáez et al., 2008). Activities of b-fu have not, to the best of our knowledge, been previously reported for the marine water column; hydrolysis rates were generally comparable to those of the other substrates measured here.

Endo-acting polysaccharide hydrolase activities in the Guaymas Basin present a different pattern than the exoacting activities: polysaccharide hydrolase activities decreased somewhat with depth, and only a subset of the polysaccharides were hydrolyzed at depths above the bottom water. The overall pattern of polysaccharide hydrolase activities was quite unusual, since a broader spectrum of polysaccharides were hydrolyzed in bottom waters than at shallower depths (Figure 2). A more typical pattern is a narrowing spectrum of polysaccharide hydrolase activities with depth (Steen et al., 2012; D'Ambrosio et al., 2014; Hoarfrost and Arnosti, 2017; Balmonte et al., 2018). Hydrolysis rates at depth in the Guaymas Basin were considerably more rapid than rates measured at comparable depths in the South Atlantic (Hoarfrost and Arnosti, 2017), but were comparable to rates measured in the deep Pacific Ocean (Balmonte and Arnosti, unpublished data). Fucoidan hydrolysis deep in the water column is quite remarkable, however, given the lack of this activity in many locations in the surface ocean (Arnosti et al., 2011) and in most of the other deep ocean locations that have been investigated, including in the Arctic (Balmonte et al., 2018), the South Atlantic (Hoarfrost and Arnosti, 2017), the Pacific (Balmonte et al., unpublished data), and the Gulf of Mexico (Steen et al., 2012). Fucoidan hydrolysis at a depth of ca $190 \mathrm{~m}$ has, however, also been measured in water collected above the sediments on the continental shelf of the northwest Atlantic Ocean (Balmonte et al., 2019).

The observation that all four polysaccharides were hydrolyzed in waters immediately above the sediments suggests a direct influence of the sediments on activities in the overlying water column, since the spectrum of polysaccharide hydrolase activities in sediments is typically much broader than in the overlying water column (e.g., Arnosti, 2000, 2008). The high influx of sediment-derived DOC into the water column (Lin et al., 2017), and elevated levels of polysaccharide-rich, transparent exopolymeric particles (TEP) in bottom waters immediately above the sediments (Prieto and Cowen, 2007) are also evidence of such a connection between the sediments and the water column. TEP are often enriched in deoxy sugarcontaining sulfated polysaccharides such as fucoidan, possibly explaining substantial fucoidanase activities in Alvin-collected waters (Figure 2).

The contrast in patterns of exo- and endo-acting activities may provide a clue as to the types of carbohydrates that are enzymatically hydrolyzed in the waters of the Guaymas Basin. In particular, the high rates of exo-acting b-xyl activities and considerable rates of exo-acting b-fu activities at the DCM and OMZ contrast sharply with the lack of measurable endoacting xylanase and fucoidanase activities at the same depths in the water column. Exo-acting enzymes hydrolyze individual monosaccharides either from the terminal end of a chain, or as branches off a complex structure. We suggest that the exoacting enzymes are therefore targeting specific branches of complex polysaccharides in the water column; deeper in the water column, particularly directly over the sediments, where both endo- and exo-acting enzymes are active, fucoidan-like and xylan-like polysaccharides (potentially sourced from the sediments) are more likely being hydrolyzed.

The generally high rates of exo-acting enzyme activities reported here are likely characteristic of the Guaymas Basin deep water column, given the overall similarity of hydrolysis rates and patterns among CTD casts collected within an area of ca. $5000 \mathrm{~m}^{2}$ over the course of a week (Figure 1). These high rates of activity likely reflect the dual sources of potential substrates in the basin: (i) an influx of hydrothermally affected dissolved organic matter (DOM) from the sediments (Lin et al., 2017), and (ii) input of sinking POM that generally reaches highest levels from November through March during winter diatom blooms (Lyons et al., 2011). In the event of a sinking diatom bloom, microbial degradation of sinking POM alters its composition toward more degradable compounds, which could also explain the depthrelated shifts in exo-acting enzyme activities (i.e., glucosidasedominated activities at the DCM; xylose-dominated activities in deeper waters) and endo-acting enzyme activities (i.e., broader spectrum of polysaccharide hydrolases at depth). Both sources of organic matter (sediment and surface waters) account for the rapid enzymatic activities at depth in the basin, with the potential to support a considerable population of heterotrophic bacteria, explaining elevated cell numbers throughout the water column (Table 1).

Investigations of microbial communities in the water column of the Guaymas Basin have demonstrated that the hydrothermal plume and non-plume (background seawater) communities are very similar in composition (Dick and Tebo, 2010; Dick, 2019). To date, heterotrophic metabolism has been little studied in Guaymas Basin; autotrophic metabolism, including oxidation of methane, and chemolithoautotrophy, has been a focus (e.g., Lesniewski et al., 2012; Anantharaman et al., 2013; Dick et al., 2013). Since gene transcripts for specific aspects of heterotrophic metabolism are not as easily assigned as for other types of metabolism, the importance of heterotrophy to microbial community metabolism cannot easily be assessed via metatranscriptomic approaches. Much remains to be discovered about the microbial communities of the Guaymas Basin: metagenomic investigation of water column communities determined that approximately $35 \%$ of $16 \mathrm{~S}$ sequences could not be identified at domain level (Lesniewski et al., 2012) and much of metatranscriptomic data could also not be assigned at a functional level function, although many of these unclassified genes were highly transcribed (Lesniewski et al., 2012). 
Although the microbial communities of the Guaymas Basin water were predominantly studied for their chemosynthetic and autotrophic capabilities (e.g., Lesniewski et al., 2012; Anantharaman et al., 2013), our results indicate that hydrothermal influence in the water column promotes active heterotrophic microbial communities as well. Rapid hydrolysis of a broad spectrum of carbohydrates at depth suggests the presence of a highly active heterotrophic microbial community deep in the Guaymas Basin fueled by DOC (Lin et al., 2017) and supplied with nutrients (Von Damm et al., 1985) produced through hydrothermal alteration of the thick layer of surfaceocean derived organic matter (Schrader et al., 1980). Further characterization of microbial heterotrophic activities and the organisms carrying it out should be a next step in investigation of this unique environment.

\section{DATA AVAILABILITY STATEMENT}

The data from this study are available on figshare at https:// figshare.com/articles/Hydrolytic_enzyme_activities_and_CTD_ data/11120501.

\section{REFERENCES}

Alderkamp, A.-C., van Rijssel, M., and Bolhuis, H. (2007). Characterization of marine bacteria and the activity of their enzyme systems involved in degradation of the algal storage glucan laminarin. FEMS Microbiol. Ecol. 59, 108-117. doi: 10.1111/j.1574-6941.2006.00219.x

Alonso-Sáez, L., Vazquez-Dominguez, E., Cardelus, C., Pinhassi, J., Sala, M. M., Lekunberri, I., et al. (2008). Factors controlling the year-round variability in carbon flux through bacteria in a coastal marine system. Ecosystems 11, 397-409. doi: 10.1007/s10021-008-9129-0

Anantharaman, K., Breier, J. A., Sheik, C. S., and Dick, G. J. (2013). Evidence for hydrogen oxidation and metabolic plasticity in widespread deep-sea sulfuroxidizing bacteria. Porc. Natl. Acad. Sci. U.S.A. 110, 330-335. doi: 10.1073/pnas. 1215340110

Arnosti, C. (1996). A new method for measuring polysaccharide hydrolysis rates in marine environments. Org. Geochem. 25, 105-115. doi: 10.1016/s01466380(96)00112-x

Arnosti, C. (2000). Substrate specificity in polysaccharide hydrolysis: contrasts between bottom water and sediments. Limnol. Oceanogr. 45, 1112-1119. doi: 10.4319/lo.2000.45.5.1112

Arnosti, C. (2003). Fluorescent derivatization of polysaccharides and carbohydrate-containing biopolymers for measurement of enzyme activities in complex media. J. Chromatogr. B 793, 181-191. doi: 10.1016/s1570-0232(03)00375-1

Arnosti, C. (2008). Functional differences between Arctic sedimentary and seawater microbial communities: contrasts in microbial hydrolysis of complex substrates. FEMS Microb. Ecol. 66, 343-351. doi: 10.1111/j.1574-6941.2008. 00587.x

Arnosti, C. (2011). Microbial extracellular enzymes and the marine carbon cycle. Ann. Rev. Mar. Sci. 3, 401-425,.

Arnosti, C., Steen, A. D., Ziervogel, K., Ghobrial, S., and Jeffrey, W. H. (2011). Latitudinal gradients in degradation of marine dissolved organic carbon. PLoS One 6:e28900. doi: 10.1371/journal.pone.0028900

Balmonte, J. P., Buckley, A., Hoarfrost, A., Ghobrial, S., Ziervogel, K., Teske, A., et al. (2019). Community structural differences shape microbial responses to high molecular weight organic matter. Environ. Microb. 21, 557-571. doi: 10.1111/1462-2920.14485

Balmonte, J. P., Teske, A., and Arnosti, C. (2018). Structure and function of high Arctic pelagic, particle-associated, and benthic bacterial communities. Environ. Microb. 20, 2941-2954. doi: 10.1111/1462-2920.14304

\section{AUTHOR CONTRIBUTIONS}

Both authors planned the research and wrote the manuscript. KZ carried out all shipboard measurements and analyzed samples post-cruise.

\section{FUNDING}

Funding for this work came from NSF OCE-0848793 and OCE1736772 to CA and UNC Office of Postdoctoral affairs to KZ. Funding for the research expedition came from NSF OCE0647633 to Andreas Teske (chief scientist).

\section{ACKNOWLEDGMENTS}

We thank Andreas Teske for the invitation to join the cruise, and the captain, crew, and scientific party of R/V Atlantis (AT 15-56) for their assistance at sea. We also thank the Martens lab at UNC for assistance with the DOC analysis. This study was supported by NSF.

Baltar, F., Aristegui, J., Gasol, J. M., Sintes, E., van Aken, H. M., and Herndl, G. J. (2010). High dissolved extracellular enzyme activity in the deep central Atlantic Ocean. Aquat. Microb. Ecol. 58, 287-302. doi: 10.3354/ame01377

Baltar, F., Aristegui, J., Sintes, E., van Aken, H. M., Gasol, J. M., and Herndl, G. J. (2009). Prokaryotic extracellular enzymatic activity in relation to biomass production and respiration in the meso- and bathypelagic waters of the (sub)tropical Atlantic. Environ. Microbiol. 11, 1998-2014. doi: 10.1111/j.14622920.2009.01922.x

Campbell, A. C., and Gieskes, J. M. (1984). Water column anomalies associated with hydrothermal activity in the Guaymas Basin, Gulf of California. Earth Planet. Sci. Lett. 6, 57-72. doi: 10.1016/0012-821x(84)90140-7

D’Ambrosio, L., Ziervogel, K., MacGregor, B., Teske, A., and Arnosti, C. (2014). Composition and enzymatic function of particle-associated and free-living bacteria: a coastal/offshore comparison. ISME J. 8, 2167-2179. doi: 10.1038/ ismej.2014.67

Dick, G. J. (2019). The microbiomes of deep-sea hydrothermal vents: distributed globally, shaped locally. Nat. Revi. Microbiol. 17, 271-283. doi: 10.1038/s41579019-0160-2

Dick, G. J., Anantharaman, K., Baker, B. J., Li, M., Reed, D. C., and Sheik, C. S. (2013). The microbiology of deep-sea hydrothermal vent plumes: ecological and biogeographic linkages to seafloor and water column habitats. Front. Microbiol. 4:124. doi: 10.3389/fmicb.2013.00124

Dick, G. J., and Tebo, B. M. (2010). Microbial diversity and biogeochemistry of the Guaymas Basin deep-sea hydrothermal plume. Environ. Microbiol. 12, 1334-1347. doi: 10.1111/j.1462-2920.2010.02177.x

Dombrowski, N., Teske, A. P., and Baker, B. J. (2018). Expansive microbial metabolic versatility and biodiversity in dynamic Guaymas Basin hydrothermal sediments. Nat. Comm. 9:4999. doi: 10.1038/s41467-018-07418-0

Einsele, G., Gieskes, J. M., Curray, J., Moore, D. M., Aguayo, E., Aubry, M.-P., et al. (1980). Intrusion of basaltic sills into highly porous sediments, and resulting hydrothermal activity in the Guaymas Basin, Gulf of California. Nature 283, 441-445. doi: 10.1038/283441a0

Hoarfrost, A., and Arnosti, C. (2017). Heterotrophic extracellular enzymatic activities in the Atlantic Ocean follow patterns across spatial and depth regimes. Front. Mar. Sci. 4:200. doi: 10.3389/fmars.2017.00200

Hoppe, H.-G. (1983). Significance of exoenzymatic activities in the ecology of brackish water: measurements by means of methylumbelliferyl-substrates. Mar. Ecol. Prog. Ser. 11, 299-308. doi: 10.3354/meps011299

Kabisch, A., Otto, A., Konig, S., Becher, D., Albrecht, D., Schuler, M., et al. (2014). Functional characterization of polysaccharide utilization loci in the marine 
Bacteroidetes ‘Gramella forsetti' KT 0803. ISME J. 8, 1492-1502. doi: 10.1038/ ismej.2014.4

Kahru, M., Marinone, S. G., Lluch-Cota, S. E., Pares-Sierra, A., and Mitchell, B. G. (2004). Ocean-color variability in the Gulf of California: scales from days to ENSO. Deep Sea Res. II Top. Stud. Oceanogr. 51, 139-146. doi: 10.1016/j.dsr2. 2003.04.001

Karner, M., Fuks, D., and Herndl, G. J. (1992). Bacterial activity along a trophic gradient. Microb. Ecol. 24, 243-257. doi: 10.1007/BF00167784

Kirchman, D. L., Dittel, A. K., Findlay, S. E. G., and Fischer, D. (2004). Changes in bacterial activity and community structure in response to dissolved organic matter in the Hudson River, New York. Aquat. Microb. Ecol. 35, 243-257. doi: $10.3354 / \mathrm{ame} 035243$

Lesniewski, R. A., Jain, S., Anantharaman, K., Schloss, P. D., and Dick, G. J. (2012). The metatranscriptome of a deep-sea hydrothermal plume is dominated by water column methanotrophs and lithotrophs. ISME J. 6, 2257-2268. doi: 10.1038/ismej.2012.63

Lin, Y.-S., Koch, B. P., Feseker, T., Ziervogel, K., Goldhammer, T., Schmidt, F., et al. (2017). Near-surface heating of young rift sediment causes mass production and discharge of reactive dissolved organic matter. Sci. Rep. 7:44864. doi: 10.1038/ srep44864

Lyons, G., Benitez-Nelson, C. R., and Thunell, R. C. (2011). Phosphorus composition of sinking particles in the Guaymas Basin, Gulf of California. Limnol. Oceanogr. 56, 1093-1105. doi: 10.4319/lo.2011.56.3. 1093

Painter, T. J. (1983). “Algal polysaccharides," in The Polysaccharides, ed. G. O. Aspinall (New York, NY: Academic Press), 195-285.

Porter, K. G., and Feig, Y. S. (1980). The use of DAPI for identifying and counting aquatic microflora. Limnol. Oceanogr. 25, 943-948. doi: 10.4319/lo.1980.25.5. 0943

Prieto, L., and Cowen, J. P. (2007). Transparent exopolymer particles in a deepsea hydrothermal system: Guaymas Basin, Gulf of California. Mar. Biol. 150, 1093-1101. doi: 10.1007/s00227-006-0430-1

Schrader, H., Kelts, K., Curray, J., Moore, D., Aguayo, E., Aubry, M. P., et al. (1980). Laminated diatomaceous sediments from the guaymas basin slope (central gulf of california): 250,000-year old climate record. Science 207, 1207-1209. doi: $10.1126 /$ science.207.4436.1207
Simoneit, B. R., Mazurek, M. A., Brenner, S., Crisp, P. T., and Kaplan, I. R. (1979). Organic geochemistry of recent sediments from Guaymas Basin, Gulf of California. Deep Sea Res. A Oceanogr. Res. Pap. 26A, 879-891. doi: 10.1016/ 0198-0149(79)90102-x

Steen, A. D., Ziervogel, K., Ghobrial, S., and Arnosti, C. (2012). Functional variation among polysaccharide-hydrolyzing microbial communities in the Gulf of Mexico. Mar. Chem. 138, 13-20. doi: 10.1016/j.marchem.2012.06.001

Teske, A., Callaghan, A. V., and LaRowe, D. E. (2014). Biosphere frontiers of subsurface life in the sedimented hydrothermal system of Guaymas Basin. Front. Microbiol. 5:362. doi: 10.3389/fmicb.2014.00362

Teske, A., Hinrichs, K.-U., Edgcomb, V., de Vera Gomez, A., Kysela, D., Sylva, S. P., et al. (2002). Microbial diversity in hydrothermal sediments in the Guaymas Basin: evidence for anaerobic methanotrophic communities. Appl.Environ. Microbiol. 68, 1994-2007. doi: 10.1128/aem.68.4.1994-2007.2002

Von Damm, K. L., Edmond, J. M., Measures, C. I., and Grant, B. (1985). Chemistry of submarine hydrothermal solutions at Guaymas Basin, Gulf of California. Geochim. Cosmochim. Acta 49, 2221-2237. doi: 10.1016/0016-7037(85)90223-6

Wegner, C.-E., Richter-Heitmann, T., Klindworth, A., Klockow, C., Richter, M., and Achstetter, T. (2013). Expression of sulfatases in Rhodopirellula baltica and the diversity of sulfatases in the genus Rhodopirellula. Mar. Genom. 9, 51-61. doi: 10.1016/j.margen.2012.12.001

Weiner, R. M., Taylor, L. E. I. I., Henrissat, B., Hauser, L., Land, M., and Coutinho, P. M. (2008). Complete genome sequence of the complex carbohydratedegrading marine bacterium, Saccharophagus degradans strain 2-40T. PLoS Genet. 5:e1000087. doi: 10.1371/journal.pgen.1000087

Conflict of Interest: The authors declare that the research was conducted in the absence of any commercial or financial relationships that could be construed as a potential conflict of interest.

Copyright (๑) 2020 Ziervogel and Arnosti. This is an open-access article distributed under the terms of the Creative Commons Attribution License (CC BY). The use, distribution or reproduction in other forums is permitted, provided the original author(s) and the copyright owner(s) are credited and that the original publication in this journal is cited, in accordance with accepted academic practice. No use, distribution or reproduction is permitted which does not comply with these terms. 